\title{
Airline Jet Fuel Hedging: Theory and practice
}

\author{
PETER MORRELL and WILLIAM SWAN
}

Department of Air Transport, Cranfield University, Bedford, UK

\begin{abstract}
Hedging fuel costs is widely practiced by most international airlines but its theoretical justification is weak. This paper explores the nature and extent of airline fuel hedging and asks why airlines hedge. A policy of permanent hedging of fuel costs should leave expected long-run profits unchanged. If it damps out profit volatility, it should do so in a way that the market would not value. However, it may not damp out volatility, after all. Oil prices and air travel demand cycles are linked when oil supply reductions drive GDP declines. But oil and travel are negatively correlated when GDP demand surges drive oil price increases. So oil prices can either increase or decrease airline profit cycles, depending on the time period sampled. A fuel price hedge would create exceptional value when an airline is on the edge of bankruptcy. However, when on the verge of bankruptcy, an airline does not have the liquidity to buy oil futures. And variable levels of hedging can be useful in transferring profits from one quarter to another. Finally, hedging may be a zero-cost signal to investors that management is technically alert. Perhaps this is the most compelling argument for airline hedging. However, it lies more in the realm of the psychology of markets than the mathematics.
\end{abstract}

Correspondence Address: Peter Morrell, Department of Air Transport, Cranfield University, MK43 0AL, UK. E-mail: p.s.morrell@cranfield.ac.uk 


\section{Introduction}

Airlines do something the industry calls 'hedging' to protect fuel costs. Hedging broadly means locking in the cost of future fuel purchases. This protects against sudden losses from rising fuel prices. Locking in fuel prices also prevents sudden gains from decreasing fuel prices. So airlines hedge fuel to stabilize fuel costs. Fuel is about $15 \%$ of the airlines' costs. Other costs are less volatile than fuel prices, so hedging fuel stabilizes overall airline costs. More stable costs also mean more stable profits.

\section{Conceptual hedge transaction}

Most fuel hedges are purchases of an oil future. A future is a contract to pay a stated price for an amount of oil on a particular date. If the airline buys a future at $\$ 22$ per barrel and oil goes up to $\$ 33$, that contract protects $\$ 22$ worth of jet fuel purchases from the expected $50 \%$ increase in price. Section 3 examines futures and derivative instruments in some detail. Airlines typically hedge between one and two thirds of their expected fuel costs. Most airlines look forward six months in their hedging. Few hedges are forward more that a year out.

\section{What hedging does}

Why airlines hedge is the topic of this paper. The commonly stated reason is that hedging stabilize fuel prices and therefore overall costs, cash flows, and profits. The implication is that the market will respond to reduced volatility in profits with a higher price for the airline's stock. This implication is deduced from the correct observation that risk has a cost in the investment marketplace. 
Airline profits are volatile for two reasons. First, travel demand is sensitive to consumer confidence, which itself is correlated with stock market performance. And second, airlines themselves are highly leveraged, in the sense that the total value of outstanding stock is a small fraction of annual incomes. Small changes in profits as a fraction of revenues make for large changes in the return to stock shares.

The theory behind airline fuel hedges is to reduce a major source of swings in profits, and thus higher prices for the airlines' stocks. This theory is confirmed by analysts who forecast airline stock prices. They observe and comment on the degree to which an airline might be hedged, whenever fuel prices themselves are uncertain.

Most traded airlines today hedge fuel costs. This has not always been the case. As recently as 15 years ago, fuel hedging was rare. European flag carriers used currency hedges long before fuel price hedges became common.

\section{Logic of hedging}

The theoretical justification for hedging fuel costs is weak. Classical investment theory holds that investors reward stocks for their performance as part of a larger portfolio. And portfolio investors can hedge oil to balance their returns at their own discretion. As we shall see later, there are conditions where hedging does help. However, the baseline case of using hedging to reduce airline profit swings is weak. There are even market reasons to avoid hedging. 


\section{Expected value is zero}

The first inescapable market fundamental is that the expected value of a fuel hedge is zero. Airlines that 'make money' hedging fuel and can rely on doing so in the future ought to open a separate division for speculating in oil prices (at least one did: United Airlines). Otherwise, the betting on oil is evenly balanced between sellers and buyers. The markets are deep, meaning they are heavily traded, liquid, and attract the attention of lots of professional traders: oil suppliers and portfolio investors alike. Airline purchases are small, and do not change the market prices. So airlines are getting the market price. And that market price represents a well-examined consensus. The expected value of such a bet is zero. If the airlines' expect otherwise, they are no longer hedging. They are speculating in oil. Nor do ex-post examples of profitable hedging justify hedging as a general practice.

The idea that the airlines profit only by chance from long-term hedging practices does not interfere with the reasoning behind hedging. Airlines are not hedging to improve profits. They are hedging to reduce the swings in profits. That is to say, they are hedging to make profits stay closer to average.

\section{Investors should not value market hedges}

The second market fundamental is that investors should not reward reduced profit volatility with higher stock prices if that reduction is effected by hedging with market instruments. The common benchmark for this kind of statement is the CAPM theory of investments (see Sharpe, 1964). CAPM says that investors average away firmspecific risk by owning a portfolio of stocks. Investors only pay for reductions in 
market risk. That is, they expect higher returns for stocks with high correlations with market moves, and lower returns for stocks with lower 'beta'. But they do not require higher returns for stocks whose profits swing a lot if those swings are independent of the general market.

It would seem if forward oil price moves were negatively correlated with market prices, then oil hedging would reduce an airline's beta. Let us assume for discussion that oil prices can counter-balance stock market moves in general. If that is the case, that value goes to the oil forward contract, and not to the airline. That is, if oil futures counterbalance market risk, they will have a price that reflects the value of that counterbalance. ${ }^{1}$ After all, if investors are clever enough to measure reduced airline beta, they are clever enough to discover oil futures on their own. ${ }^{2}$ As the airlines take the oil future risk with their own funds, the investor should find the combined package no more valuable than before. That is, the reduction in risk for the airline investment is exactly worth the oil contract's cost.

\section{Hedging near bankruptcy}

There is one exception to the efficient market principles. When an airline is near bankruptcy, hedging fuel prices may make sense. Bankruptcy brings with it additional losses, as the airline is either sold in pieces, or operated on a cash basis under expensive supervision. An airline near bankruptcy would like to protect itself from excursion into losses and a thus the expenses of becoming bankrupt. In this situation it pays to insure against sudden fuel price increases that would cause failure. Unfortunately, it is at this very moment that acquiring oil price forward contracts is impossible. Contracting future prices requires a guarantee that the company can pay the losses if the contract goes against the airline. No one wants a bet with someone 
who cannot pay off if they loose. An airline near bankruptcy cannot come up with the margin requirements to back futures commitments. They cannot post a credible bond. The authors have knowledge of several airline bankruptcies and in every case, financial officers recognized the advantage of a hedge, and understood that they were not in a position to make the appropriate trades.

There is a way to hedge that does not require a margin. Airlines can buy a 'call' option that pays off above some upper bound on oil prices. However, these options cost cash. In the one case where this was explored, the airline at risk could not make their business plan work if they had to pay for the oil price options. In short, by the time oil price risk is more costly to the airline than to the oil market, the airline cannot fund removing the risk.

\section{The practice of fuel price hedging}

\section{Hedging instruments available}

Up to now the discussion has assumed fuel hedging used futures contracts. In practice, fuel price risk can be managed in a number of ways:

- $\quad$ Forward contracts

- $\quad$ Futures contracts

- Options, collars, swaps etc

Forward contracts are 'over the counter' agreements between two parties whereby one purchases a fixed amount of fuel from the other at a fixed price at some future date. Airline fuel suppliers such as BP Air enter into such agreements, but their tailor-made 
nature is not a convenient instrument for third parties or speculators. The purchaser also has full counter-party risk.

Futures are better suited to both hedging and trading, since they are usually through exchanges that set standard contracts. One party to the contract agrees to deliver to another a standardised quantity of oil at an agreed price (the 'strike' price) on an agreed date in the future. These can be easily reversed before due date so that no physical delivery need take place. In fact, according to NYMEX, less than $1 \%$ of trades actually result in the delivery of the underlying commodity, in this case crude oil and related products.

The main exchanges offering these contracts are the International Petroleum Exchange (IPE) in London and NYMEX in New York. The former's future is in Brent crude oil, one contract being for 1,000 barrels. The quality of the oil is assured, and contracts can be fixed for each month up to two years ahead, and then half-yearly to three years out. The liquidity for contracts beyond one year forward declines significantly. There is a Clearing House that guarantees the financial performance of contracts with the help of margin requirements.

Options are available in both Brent gas oil and crude at IPE. They are based on the underlying futures and if exercised (there no obligation to do so) will result in a corresponding futures position. Options offer added flexibility over futures, giving holders the possibility to protect themselves against adverse price movements, while at the same time giving them the opportunity to participate in favourable movements. Options (and swaps) can also be taken out with other parties (e.g. approved counterparties such as banks) in aviation fuel. 
Jet fuel is rarely traded on any exchanges and thus must be 'over the counter'. These involve counter-party risk for both sides, and thus financially weak airlines would find it hard to find others willing to take this risk.

More recently airlines have moved toward using combinations of a call and a put option called a collar. The call protects the holder from adverse price increases above its strike price, at a cost of the option premium that must be paid in any event. The holder of this call also writes a put option that limits the advantage it can take of price reductions below its strike price. The total cost of taking the two options is the call option premium paid less the put option premium received. This is popular with airlines since it locks in the price that will be paid for fuel between two known values. A collar limits the speculative risk to a small range of price moves.

Swaps are tailor-made futures contracts whereby an airline exchanges payments at a future date (which can be in jet aviation fuel and could be further into the future than possible through commodity exchanges), based on the fuel or oil price. These could be arranged with a supplier such as Air BP. The airline would buy a swap for a period of, say, one year at a certain strike price for a specified amount of jet fuel per month. The average price for that month is then compared with the strike price, and if it exceeds it the counter-party would pay the airline the difference times the amount of fuel. However, if it were lower, then the airline would pay the difference. They lock in a given price, as with forward contracts.

In summary, aviation fuel itself can only be hedged through over-the-counter arrangements with the additional counter-party risk. Hedging oil on exchanges such as NYMEX or SIMEX that regulate standardised contracts eliminates counter-party risk. These also are more liquid, and allow an airline to sell before due date. For 
longer periods into the future only crude oil instruments have good liquidity. Jet fuel contracts only have liquidity for shorter periods.

\section{Hedging instrument suitability}

Hedging using jet kerosene clearly fully reflects price movements in the commodity that the airline actually needs to operate its aircraft. ${ }^{3}$ Apart from a little-traded Japanese market, there are no exchange-traded futures available in aviation fuel, although over-the-counter contracts can be arranged.

The most liquid market available for the most closely related product is crude oil, with contracts available in both Brent and US WTI crudes. No markets exist for OPEC produced oil products, although the market prices for these track very closely the above two supplies.

Insert figure 1 about here

Figure 1 shows trends in both jet kerosene and crude prices between 1989 and 2003. The premium for jet kerosene varies from around 5 cents to 15 cents. The wider divergence of jet aviation fuel prices from crude prices tends to occur at times of greater volatility in crude prices. This is especially when the original cause of the volatility was war or threat of war. This leads to greater military use of diesel and gasoline and a switch of production to these fractions (which might also be stockpiled). At the same time there might be a significantly greater demand for jet fuel from the military. This means that crude and heating oil are not always an ideal hedge against jet aviation price increases. 
Aviation fuel is almost always priced in US dollars, as are oil derivative contracts. ${ }^{4}$ Airlines are thus faced with the risk of exchange rate movements, where they do not have adequate natural hedge cover. Few airlines outside the US have sufficient revenues in US dollars to provide such cover. However, it is sometimes the case that exchange rates move in such a way as to mitigate increases in fuel prices. This was the case in 2004 for many EU carriers, when the weaker dollar offset some of the dollar fuel price increase. Most of the larger airlines have hedged foreign exchange risks for many years.

\section{Who hedges?}

\section{Airline approaches to fuel price volatility}

Airlines do not have long-term contracts with fuel suppliers, and are thus faced with volatile input prices. Their contracts are usually linked to the monthly price quoted by Platts, and are usually for no longer than one year. Every $10 \%$ increase in fuel prices can reduce operating margins by $1.7 \%$ for American Airlines.

How can airlines address this problem?

- Increase fuel efficiency

- $\quad$ Pass on increases to their customers

- Hedge future fuel requirements using physical and derivative markets

Increasing fuel efficiency in the short-term relies on changing operating procedures (e.g. cruise speed) or tankering policies. Most of these are already exhausted, and there are limits to how much can be achieved, given safety 
requirements. Replacing existing aircraft with more fuel efficient ones can take place gradually. This has the same effect as a permanent policy of hedging fuel. It reduces profit volatility due to fuel price moves.

Airlines have passed fuel increases on to customers on the cargo side of the business for many years. Lufthansa and others publish an index of fuel prices, and the trigger points and resulting surcharge amounts. FedEx does not hedge fuel at all since it can rely largely on these surcharges.

On the passenger side, surcharges are more rare, but recently most of the major EU airlines have done this with some success. On the other hand, US airlines operating within the US seldom make such increases stick. Low cost airlines there now account for near one third of capacity, and the competitive situation is more intense than in other parts of the world.

It is also the norm in many other industries to pass on increases in input prices in the short term, while investing in more fuel-efficient systems in the longer term. Table 1 shows that many European airlines differentiated their surcharges between short and long-haul trips. Interestingly, KLM's approach was very different to that of their new owner, Air France. In Asia, there was a larger variation in surcharge amounts, while only one US airline had introduced surcharges on international flights by August 2004.

Table 2 shows typical market (end-user) prices faced by American since 1989, and the average price they actually accounted for each year, after paying tax and offsetting any gain or loss from hedging. 
Since 2000, AMR have also reported the gains they made on fuel hedging, and so for these years it was possible to calculate their pre-hedging price. They also give the percentage of each year's projected fuel consumption that was hedged on 31 December of previous year. It can be seen that they were most successful in 2000, when end-user prices rose by $66 \%$ compared to 1999, but AMR's average price (after a gain of $\$ 545$ million on hedging operations) only increased by $42 \%$. In the following year (2001) they did not do so well, but reported a gain of \$29 million on hedging when the market price declined by $14 \%$. However, most of the drop was in the second half of the year, when AMR might have been less covered, and thus able to enjoy some of the downside.

British Airways also reported a large gain of nearly $£ 300$ million (around US\$400m) on fuel hedging for their financial year ended 31 March 2001, but reported a loss of $£ 75$ million (US\$108m) for the following year (British Airways, 2005). Singapore Airlines also reported a fuel hedging loss of $\$ \$ 212$ million (US\$117m) for the same financial year 2001/02, after smaller profits for the previous year.

AMR reported that they were only $12 \%$ covered at the end of 2003 for 2004 consumption (at an equivalent price of just under $\$ 28$ a barrel). This low level was presumably because they thought that the price levels towards the end of 2003 could not be sustained, but also because they could not afford to use scarce cash for swap collateral.

Insert table 2 about here 
For example, in October 2003, Brent Crude 3 month futures were trading at a discount of 5-6\% to spot physicals, showing that the market was expecting a fall in 2004. This was generally the case, apart from over June 2004 and very briefly in December 2003 (figure 2).

Insert figure 2 about here

\section{Which airlines hedge}

Most major passenger airlines now hedge at least part of their future fuel needs. A survey of treasurers from 25 of the world's largest airlines in 1991 revealed that 13 engaged in fuel futures transactions, managing exposures six months to two years into the future (KPMG/IATA, 1992). Some state owned airlines such as Air India were only given permission by their central bank to hedge more recently in 2003 .

Three of the eight largest US majors were not hedged for 2004, and one was only hedged for six months of that year.

Insert table 3 about here

All the major European network airlines had hedged a significant part of their 2005/05 fuel needs at the date of publication of their latest annual report. British Airways were somewhat under-covered, but subsequently increased their hedging activity (table 4).

Insert table 4 about here 
Less information was available from the annual reports of Asian airlines. However, in general, less hedging seems to have been undertaken by the still predominately state owned airlines. Both Thai Airways and Malyasian reported an upper limit of $50 \%$ on the volume of expected fuel uplift that could be hedged, with All Nippon also reporting an unspecified limit.

Korean Airlines reported a gain of Won 282 million from a forward fuel contract in FY2003, reducing their average fuel price paid by 34\%. Qantas offset $73 \%$ of their 2003/04 increased fuel price paid through various unspecified hedging activities. Singapore Airlines were able to offset almost all the price element of their 2002/03 increase in fuel costs by hedging, and in the following financial year a $\mathrm{S} \$ 135 \mathrm{~m}$ fuel cost increase from higher prices was made $\mathrm{S} \$ 1 \mathrm{~m}$ worse by hedging losses.

The major Chinese airlines (e.g. China Southern, China Eastern and Air China) were (as at end 2004) obliged to purchase their domestic fuel needs from the state oil company at PRC spot prices. They were also not permitted to hedge fuel (or foreign exchange) price risk.

\section{Which hedging instruments airlines use}

As discussed in 3.2 above, futures are used by some airlines, but the most popular forms of fuel price hedging are options, swaps and collars. The latter are seen as being less speculative. Crude and heating oil contracts are more widely used than jet kerosene, since they can be traded on an exchange. Airlines rarely cover more than 18 months to 2 years into the future, with most treasurers looking to cover a part of requirements over the next budget or financial year. 
Many airlines are finding it increasingly difficult and expensive to access credit for fuel hedging purposes. To alleviate this problem and to reduce the costs associated with risk premiums IATA is working with leading banks worldwide to use the IATA Clearing House for the settlement of hedging transactions.

\section{Tests in literature}

\section{Hedging tests: foreign exchange}

Previous studies have tended to focus more on foreign currency risk than fuel price risk. Their starting point has been the CAPM assertion that risk management is irrelevant to firm value since shareholders are better placed to do this themselves. The counter argument is that in the real world the CAPM theory does not hold because of factors such as taxation, access to information and economies of scale in hedging operations.

Allayanis and Weston (2001) examined foreign currency derivative users in a large sample of non-financial US firms between 1990 and 1995. They found that those that used currency hedging had, on average, a $4.87 \%$ higher firm value (measured as Tobin's Q) than firms that did not. Their model explained variations in Q using a number of different factors in addition to hedging. A dummy variable was used to distinguish those firms that did hedge from those that did not. This was because of the lack of more detailed data on hedging; the period they chose was dictated by the lack of any data prior to 1990 . Thus the research was not able to take into account the difference between those firms that might have hedged $100 \%$ of their currency needs one year ahead, and those that only hedged $20 \%$ of needs; and second, between those that hedged three months out and those that hedged two years out. 
Hedging tests: oil

Carter et al. (2003) essentially applied the Allayanis and Weston (2001) methodology to airline fuel price hedging. They reach similar conclusions: airlines that employ hedging trade at a premium. They also assert that this allows them to conserve cash at times of industry downturn (which coincides with fuel price spikes), giving them the possibility to buy assets at distressed prices. This does not seem to be supported by evidence, and indeed larger airlines that are hedging are also usually cutting back on new capital investment following a major downturn.

Cobbs and Wolf (2004) repeat the Carter results above as a rebuttal to the British Airways CEO Rod Eddington's statement that 'a lot is said about hedging strategy, most of it well wide of the mark. I don't think any sensible airline believes that by hedging it saves on its fuel bills. You just flatten out the bumps and remove the spikes' ${ }^{5}$

Rao (1999) takes a different approach by estimating how much better off an airline would be if it had bought different heating oil futures at different periods of time. He concluded that quarterly income volatility would have declined by $23 \%$ on the basis of following his assumed hedging policy. The author admits that the use of a fictional airline may have inflated the advantage of hedging. He also assumes that the purchase of futures is costless and the marking to market requirement of some accounting requirements ignored.

Marking to market means accounting for gains or losses in any outstanding unrealised derivatives position at the end of each financial reporting period (quarter). This may introduce a new source of volatility in earnings. The latest accounting standards recommend making these value adjustments only on the balance sheet, 
where the hedge is expected to be effective throughout its life. Where it is not and its price movements are not perfectly correlated with jet fuel prices, adjustments will have to be made to reported profits.

Much research has been undertaken in examining the relationship between oil price movements (and shocks) and both economic activity and corporate profitability (and stock prices). Indirectly, this becomes an exploration of whether oil futures have a beta, as discussed in section 6. Contrasting results were reported for the impact on stock prices: Jones and Kaul (1996) found that oil prices do have an effect on aggregate stock returns, while Huang et al. (1996) found no evidence of any correlation between oil price future returns and aggregate stock returns. Sadorsky (1999) found that positive shocks to oil prices tend to depress real stock returns, which in turn effect interest rates and industrial production (and thus economic growth). J P Morgan (2001) found 'little correlation between the price of jet fuel and airlines' relative performance on the stock market'.

\section{Discussion}

\section{Oil prices sometimes move counter to travel demand}

Fuel hedges can either decrease or increase volatility. Profit swings will be damped when fuel prices surge at the same time travel demand falters. Most hedging is said to be aimed at protecting profits against a sudden up-turn in fuel prices. The cases uppermost in peoples' minds seem to be the rise of oil prices caused by warfare in the Middle East. Supply limitations can come from OPEC succeeding at rationing production, from political actions with secondary suppliers such as Venezuela or 
Nigeria, from military action such as the invasion of Kuwait, or from vandalism by international terrorists. The decrease in oil supply is usually accompanied by losses in consumer and business confidence. Acting together, higher oil prices and lower confidence slow economic activity. And slowed economies and lower confidence both reduce air travel. So the profits from having purchased oil futures at lower prices counterbalance the losses from lower travel revenues and higher jet fuel expenses. An airline could contemplate hedging more than $100 \%$ of its jet fuel, if it expected a fall in revenues to happen at the same time as a rise in fuel prices.

\section{Oil prices sometimes move with travel demand}

Hedging increases volatility, in the alternative scenario for oil price increases. The second driver of fuel price swings is demand. That is, when the economy grows fast, oil demand rises. This drives prices up. Oil producers imperfectly balance the ups and downs of demand for oil with increases or decreases in production. And when higher demand makes supply tight, OPEC finds it easier to establish production limits. On the other hand, when demand drops below production plans, market prices become more competitive. The collusive actions of OPEC add to the cost-based supply curve in moving oil prices in parallel with economic growth. Add on, air travel also responds to economic cycles. Travel grows once as a fundamental with economic activity levels, and once again with cycles of consumer and producer confidence. When world Gross Domestic Product (GDP) is driving oil prices, the value of oil forward contracts will be high at the same time that air travel demand is high, and low when air travel demand is low. In these situations, profits from hedging coincide with high airline operating profits, and hedging adds to airline 
operating losses when air travel is less profitable. The economic cycle is made worse by hedging, not better, when oil price moves are demand- rather than supply-driven.

\section{Results depend on time period studied}

Whether hedging on average smoothes or exacerbates airline profit cycles depends on what time period is used to measure the correlation of fuel price changes and airline operating results. The selection of periods that cover major Middle Eastern events will demonstrate that hedging reduces volatility. By selecting periods where Middle Eastern politics were calm, one finds that hedging increases volatility. Figure 3 compares oil spot prices with detrended US stock market moves. Figure 4 shows that the correlation of oil and stock market moves back and forth from positive to negative. The particular correlation shown in figure 4 is a centered, moving, 3-year window.

Insert figure 3 about here

Thus the answer to 'does hedging reduce volatility?' is 'sometimes'. Airlines that hedge in anticipation of political uncertainty in major oil-producing regions but do not hedge when such activity is unlikely could be reducing volatility. However, that simply says that airlines that make money in the long run with their fuel hedges also reduce their profit volatilities. And airlines that can predictably make money speculating in oil prices will always do better than airlines without this exceptional ability, or luck. 


\section{Hedging can alter the timing of profits}

However, the real reason for airlines hedging fuel prices may not be economic. The discussion has focused on the pure case of an airline that consistently hedges, gets no long-run profits from hedging itself, and seeks merely to damp the swings in corporate profits. Airlines may hedge intermittently, and for reasons not associated with the expected profitability of the hedges.

Airlines can move profits forward or backwards by timing the sale of their oil futures. If profits are falling, but oil futures are in the money, the contracts can be sold before their closing date for immediate profits. This moves cash flow to an earlier quarter, since the degree and timing of hedging is not public until well after the fact. This means an airline can 'show' profits or cover losses in quarterly reports at the expense of lower profits in the later quarter, when the hedges were due. Recently, most of the unrealised value changes are required to be shown on the balance sheet, but not in the income statement. This means airlines can still move profits around by timely sales of profitable contracts before their expiry dates.

In practice, cash-strapped airlines do this. In the search for liquidity, they sell the profitable oil contracts early. Delta Air Lines settled all their fuel hedge contracts prior to their maturity in February 2004, receiving proceeds of US\$83 million almost all of which added to profits (Delta Air Lines, 2005, F-22). In the absence of liquidity, the very same airlines are unable to raise the margin requirements for making further oil forward contracts in the more distant future. So they reduce their level of fuel hedging in the face of short-term profit downswings. Investors see immediate reports that understate the degree of immediate losses, and they do not see the reduced hedging further ahead. 
During labour contract negotiations airlines may wish to delay reporting profits. This would mislead the long-term stakeholders (the employees and their union leaders) at the expense of also misleading short-term stakeholders (the stock holders). Of course the justification is that the labour contracts could be more favourable to the stockholders than otherwise. The authors are not aware of hedging used in this manner, but have frequently seen manipulation of fleet sales and other expressions of the desire to alter the timing of profits.

Variable hedging might lower stock values by confusing profit signals

Airlines that change the amounts of their hedging increase the uncertainty of their stock, as an investment in the longer term. If quarterly profits are masked by changing fuel hedging levels, then the quarterly profit information becomes less useful in predicting how well the fundamental airline activity is doing. Investors value predictability. So this could reduce stock values. At least in theory.

Airlines that move profits may be doing themselves a disservice in that they decrease the visibility of the performance of their basic business. However, in practice such moves are made only as bankruptcy approaches. In these cases, hedging is only one of many changes in the face of needs for immediate cash. Airlines will also run advance-purchase sales to collect current revenues against future transportation liabilities, and eliminate investments in personnel, relationships, equipment, and inventories at the expense of future higher costs or lower revenues. Many of these moves are far more distortionary than variable hedging. 


\section{Hedging as a signal of management competence}

Market fundamentals claim hedging is without excess profit, and that any reduction in profit volatility is not valued by the marketplace. If this is true, why do so many airlines hedge, and why do stock analysts comment on it?

Hedging could be a fashion statement. If hedging is of no economic value, it is also of no economic cost. If industry analysts consider hedging as a sign of competent management, then management is motivated to accommodate the fashion, and the stock price is suitably rewarded. It could even be that early analyst comments on hedging were intended merely to indicate the need for adjustments when comparing the profit streams of different airlines through economic cycles. At some point the observations suggested market interest in hedging, possibly implying approval. And once hedging sends the market signal that an airline is well-managed, it becomes sensible to hedge. This would be reinforced by the reverse-causality that airlines near bankruptcy cannot hedge. So airlines that hedge collectively outperform those that do not.

It is true today that both industry and supplier managers believe hedging is a sign of competent airline management. Many of these managers have skills and education in areas other than finance. Indeed, chief financial officers and the treasury departments of suppliers seem less fascinated by hedging than management in general. The idea that hedging is merely an external sign of alert management, and not a fundamental economic benefit, is difficult to test. However, markets themselves are susceptible to 'bubbles' of confidence. This could turn out to be one.

\section{Conclusions}


Most of the major airlines are hedging fuel using jet fuel, gas oil and crude derivatives. Few cover more than 12 months' expected consumption, and it is rare to find more than $80 \%$ of future needs hedged beyond three months ahead. Crude oil provides more liquidity and flexibility for hedging, but the spread between crude and jet aviation fuel had tended to widen at times of market instability. Not many airlines report gains and losses from fuel hedging activity, but many are now required to report the market value of unexpired contracts on their balance sheets.

There seems to be no reason to contradict the economic fundamentals of hedging. A policy of permanent hedging of fuel costs should leave expected long-run profits unchanged. If it damps out profit volatility, it should do so in a way that the market would not value. Data suggests it may not damp out volatility, after all. Oil prices and air travel demand cycles are correlated when oil supply reductions drive GDP declines. But oil and travel are negatively correlated when GDP demand surges drive oil price increases. So oil prices can be observed to either increase or decrease airline profit cycles, depending on the time period sampled.

A fuel price hedge would create exceptional value is when an airline is on the edge of bankruptcy. However, when on the verge of bankruptcy, an airline does not have the liquidity to buy oil futures. On the other hand, foreign exchange hedges probably did make sense, when airlines were state-supported. And variable levels of hedging can be useful in transferring profits from one quarter to another.

Finally, hedging may be a zero-cost signal to investors that management is technically alert. Perhaps this is the most compelling argument for airline hedging. However, it lies more in the realm of the psychology of markets than the mathematics of economics. 


\section{Notes}

1. Indeed, if oil futures have a negative beta, the value will appear as a premium in the future price over the expected value of oil. The expected loss would be the market's payment for the value of the negative beta risk. This as been offered as a possible explanation for six-year futures in 2005 being above the inflationadjusted cost of new long-run alternative fuel sources, such as Canadian oil shale.

2. The original version of CAPM defined the 'market' as only stocks. A broader CAPM theory includes all investment vehicles—bonds, real estate, commodities, and futures including oil—in the total market and its beta.

3. Leaving aside the aviation gasoline that airlines operating small piston-engined aircraft require.

4. There are rare occasions when prices are quoted in local currency, and some airlines ask for the transport element in fuel prices to be charged separately in local currency (since this cost is incurred in local currency).

5. AFX News article, 17 May 2004 


\section{References}

Allayannis, G. and Weston, J.P. (2001) The use of foreign currency derivatives and firm market value, The Review of Financial Studies, 14(1), pp. 243-276

British Airways (2005) Release of financial information 2004/05 under IFRS, www.ba.com (Investor Relations), July

Carter, D.A., Rogers, D.A. and Simkins, B.J. (2003) Does fuel hedging make economic sense? The case of the US airline industry, Journal of Finance website, December

Cobbs, R. and Wolf, A. (2004) Jet fuel hedging strategies: options available for airlines and a survey of industry practices, Finance, 467, Spring

Delta Air Lines (2005) Annual Report 2004, www.delta.com (Investor Relations), March

Huang, R.D., Masulis, R.W. and Stoll, H.R. (1996) Energy shocks and financial markets, Journal of Futures Marketing, 16(1), pp. 1-27

Jones, C.M. and Kaul, G. (1996) Oil and the stock markets, Journal of Finance, 51(2), pp. $463-491$

J. P. Morgan (2001) Low-fare airline industry, Industry analysis from J.P.Morgan Securities Ltd, 6 March

KPMG/IATA (1992) Accounting policies, disclosure and financial trends in the international airline industry, KPMG, August

Rao, V.K. (1999) Fuel price risk management using futures, Journal of Air Transport Management, 5, pp. 39-44

Sadorsky, P. (1999) Oil price shocks and stock market activity, Energy Economics, 21, pp. 449-469 
Sharpe, William F._(1964) Capital Asset Prices: A Theory of Market Equilibrium under Conditions of Risk, Journal of Finance, 19(3), pp. 425-442

Deleted: 1964 
Table 1. Fuel surcharges announced by major airlines in 2004

\begin{tabular}{|c|c|c|c|}
\hline & & \multicolumn{2}{|c|}{ US\$ or equivalent* } \\
\hline & \multicolumn{3}{|c|}{ Short/ medium } \\
\hline Airline & Date & haul & Long haul \\
\hline \multicolumn{4}{|l|}{ Europe: } \\
\hline Air France & Aug-04 & 3.66 & 14.64 \\
\hline British Airways & Aug-04 & 4.55 & 10.92 \\
\hline bmi & Aug-04 & 4.55 & 10.92 \\
\hline KLM & Aug-04 & 4.88 & 4.88 \\
\hline Lufthansa & Aug-04 & 2.44 & 8.54 \\
\hline \multicolumn{4}{|l|}{ North America: } \\
\hline United Airlines & Jun-04 & $\mathrm{n} / \mathrm{a}$ & $5 \%$ \\
\hline \multicolumn{4}{|l|}{ Asia/Pacific: } \\
\hline Air China & $2004 ?$ & 7.00 & 7.00 \\
\hline Air New Zealand & May-04 & $3.93-9.83$ & 13.11 \\
\hline All Nippon & May-04 & $5 \%$ & $5 \%$ \\
\hline Cathay Pacific & Aug-04 & $\mathrm{n} / \mathrm{a}$ & $13.85-18.97$ \\
\hline China Eastern & $2004 ?$ & 7.00 & 7.00 \\
\hline China Southern & $2004 ?$ & 7.00 & 7.00 \\
\hline Dragonair & Aug-04 & $5.38-6.92$ & $\mathrm{n} / \mathrm{a}$ \\
\hline Qantas & Aug-04 & 7.11 & 15.64 \\
\hline Singapore & Aug-04 & $4-7$ & 12 \\
\hline Virgin Blue & Aug-04 & 7.11 & $\mathrm{n} / \mathrm{a}$ \\
\hline
\end{tabular}

* converted at average exchange rates in August 2004 
Table 2. American Airlines (AMR Corp.) and market jet fuel price trends

\begin{tabular}{|c|c|c|c|c|c|}
\hline & \multicolumn{5}{|c|}{ AMR Corporation } \\
\hline & & & & Average fuel price & Consumption \\
\hline & Average fuel & Average fuel & & (incl.tax) pre- & hedged at end of \\
\hline & price (incl.tax) & price (ex.tax) & $\operatorname{Tax}$ & hedging & previous year* \\
\hline & US cents/gallon & US cents/gallon & $\%$ & US cents/gallon & $\%$ \\
\hline 1989 & 61.0 & $\mathrm{n} / \mathrm{a}$ & $\mathrm{n} / \mathrm{a}$ & $\mathrm{n} / \mathrm{a}$ & $\mathrm{n} / \mathrm{a}$ \\
\hline 1990 & 79.2 & $\mathrm{n} / \mathrm{a}$ & $\mathrm{n} / \mathrm{a}$ & $\mathrm{n} / \mathrm{a}$ & $\mathrm{n} / \mathrm{a}$ \\
\hline 1991 & 70.5 & $\mathrm{n} / \mathrm{a}$ & $\mathrm{n} / \mathrm{a}$ & $\mathrm{n} / \mathrm{a}$ & $\mathrm{n} / \mathrm{a}$ \\
\hline 1992 & 65.1 & 62.5 & 4.2 & $\mathrm{n} / \mathrm{a}$ & $\mathrm{n} / \mathrm{a}$ \\
\hline 1993 & 61.8 & 59.1 & 4.6 & $\mathrm{n} / \mathrm{a}$ & $\mathrm{n} / \mathrm{a}$ \\
\hline 1994 & 56.7 & 54.2 & 4.6 & $\mathrm{n} / \mathrm{a}$ & $\mathrm{n} / \mathrm{a}$ \\
\hline 1995 & 56.9 & 53.8 & 5.8 & $\mathrm{n} / \mathrm{a}$ & $\mathrm{n} / \mathrm{a}$ \\
\hline 1996 & 68.2 & 63.3 & 7.7 & $\mathrm{n} / \mathrm{a}$ & $\mathrm{n} / \mathrm{a}$ \\
\hline 1997 & 67.1 & 62.1 & 8.1 & $\mathrm{n} / \mathrm{a}$ & 12 \\
\hline 1998 & 54.9 & 50.2 & 9.4 & $\mathrm{n} / \mathrm{a}$ & 23 \\
\hline 1999 & 55.0 & 50.4 & 9.1 & $\mathrm{n} / \mathrm{a}$ & 48 \\
\hline 2000 & 78.1 & 72.8 & 7.3 & 99.9 & 48 \\
\hline 2001 & 81.4 & 76.4 & 6.5 & 82.2 & 40 \\
\hline 2002 & 76.2 & $\mathrm{n} / \mathrm{a}$ & $\mathrm{n} / \mathrm{a}$ & 76.3 & 40 \\
\hline 2003 & 87.7 & $\mathrm{n} / \mathrm{a}$ & $\mathrm{n} / \mathrm{a}$ & 92.7 & 32 \\
\hline
\end{tabular}

* Percentage of that year's projected fuel consumption which was hedged on 31 December of previous year Source: US Energy Information Administration and AMR Form 10K annual reports 
Table 3. Percentage of 2004 fuel needs hedged at 31/12/2003: US Majors

\begin{tabular}{|c|c|c|c|c|c|}
\hline & & Av. US & & & \\
\hline & $\%$ hedged & cents/gallon & Value \$ & Product & Instruments \\
\hline Southwest & 82 & $\mathrm{n} / \mathrm{a}$ & 251 & Crude \& heating & 1 Options, collars \& swaps \\
\hline Delta & 32 & 76.46 & 97 & Crude \& heating & \\
\hline US Airways & 30 & $\mathrm{n} / \mathrm{a}$ & 38 & Crude \& heating & 1 Swaps \& collars \\
\hline American* & 12 & $\mathrm{n} / \mathrm{a}$ & 54 & Jet fuel \& crude & Swaps \& options \\
\hline America West & 11 & $\mathrm{n} / \mathrm{a}$ & 21 & $\mathrm{n} / \mathrm{a}$ & Collars \\
\hline Continental & 0 & & & & \\
\hline Northwest & 0 & & & & \\
\hline United & 0 & & & & \\
\hline
\end{tabular}

* Approximate average for whole year; 21\% hedged for first quarter Source: Airline 10K reports for 2003 
Table 4. Percentage of FY2004/05 fuel needs hedged at YE2003/04: Largest non-US carriers

\begin{tabular}{|c|c|c|c|c|c|}
\hline & & Av. & & & \\
\hline & $\%$ hedged* & cents/gallon* & Value $* * \$ m$ & Products & Instruments \\
\hline \multicolumn{6}{|l|}{ British Airways } \\
\hline$(2003 / 04)$ & 41 & 68.1 & 53 & $\mathrm{n} / \mathrm{a}$ & Collars \& swaps \\
\hline KLM (2003/04) & 80 & $\mathrm{n} / \mathrm{a}$ & $\mathrm{n} / \mathrm{a}$ & & $\mathrm{n} / \mathrm{a}$ \\
\hline Air France (2003/04) & 78 & $\mathrm{n} / \mathrm{a}$ & $\mathrm{n} / \mathrm{a}$ & & $\mathrm{n} / \mathrm{a}$ \\
\hline Iberia (2003) & 54 & $55-62$ & $\mathrm{n} / \mathrm{a}$ & Jet NWE & Swaps \& options \\
\hline Lufthansa (2003) & 72 & $72.6^{*}$ & 72 & Crude/heating oil & $\mathrm{ln} / \mathrm{a}$ \\
\hline \multicolumn{6}{|l|}{ Air New Zealand } \\
\hline$(2003 / 04)$ & 47 & bands & 84 & WTI crude \& jet & Options \& collars \\
\hline Cathay Pacific (2003) & 25 & $\mathrm{n} / \mathrm{a}$ & $\mathrm{n} / \mathrm{a}$ & $\mathrm{n} / \mathrm{a}$ & Various \\
\hline \multicolumn{6}{|l|}{ Singapore Airlines } \\
\hline$(2003 / 04)$ & $\mathrm{n} / \mathrm{a}$ & $\mathrm{n} / \mathrm{a}$ & 59 & & Options \& swaps \\
\hline Thai Airways (2003/04) & 12 & & & & Various \\
\hline Emirates $(2003 / 04)$ & 19 & $\mathrm{n} / \mathrm{a}$ & $\mathrm{n} / \mathrm{a}$ & $\mathrm{n} / \mathrm{a}$ & Options \& futures \\
\hline
\end{tabular}

* average price locked into to hedge contracts (for Lufthansa on only 35\% of annual needs)

** market value of fuel hedge derivatives at financial year end

Source: Airline annual reports and websites. 


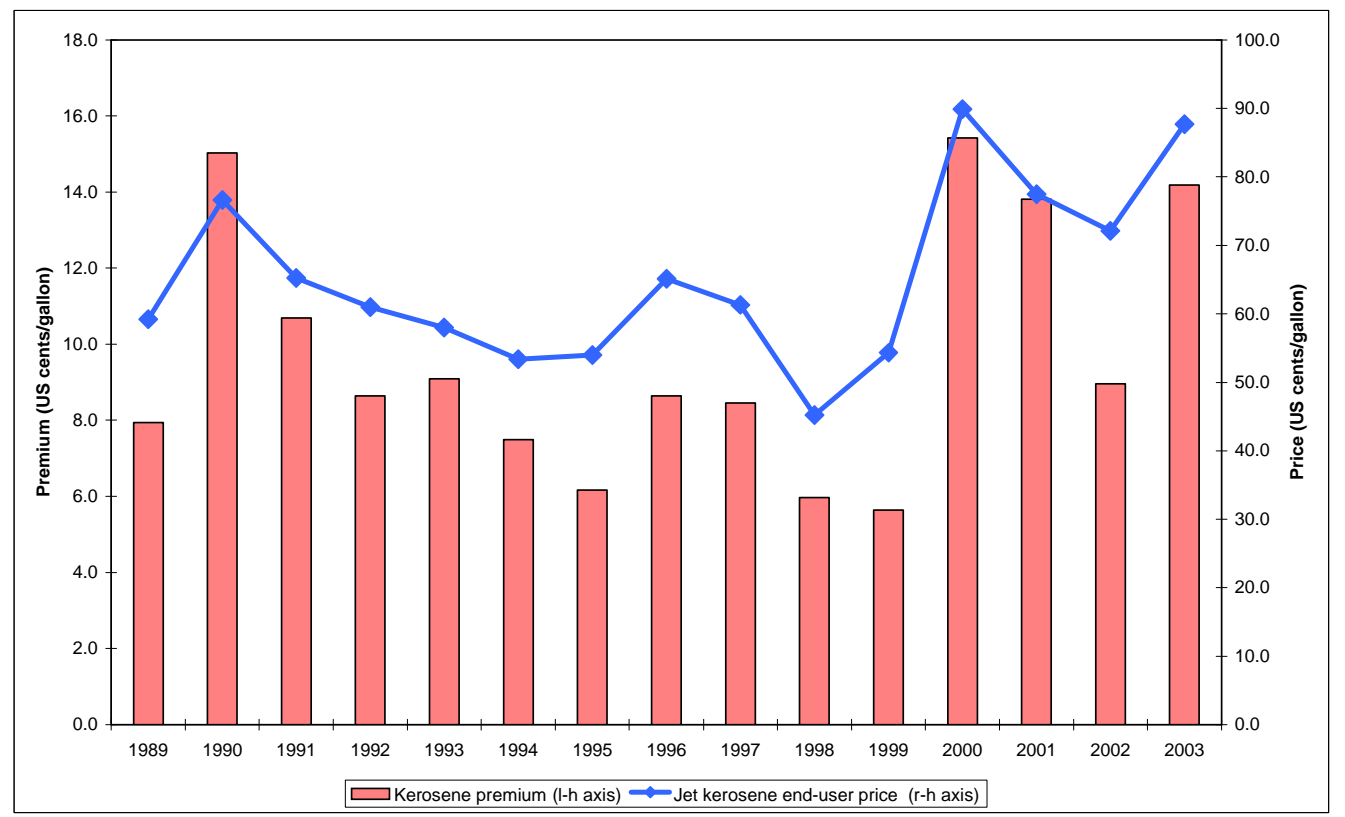

Figure 1. End-user jet kerosene price vs. crude equivalent

Source: US Energy Information Administration 


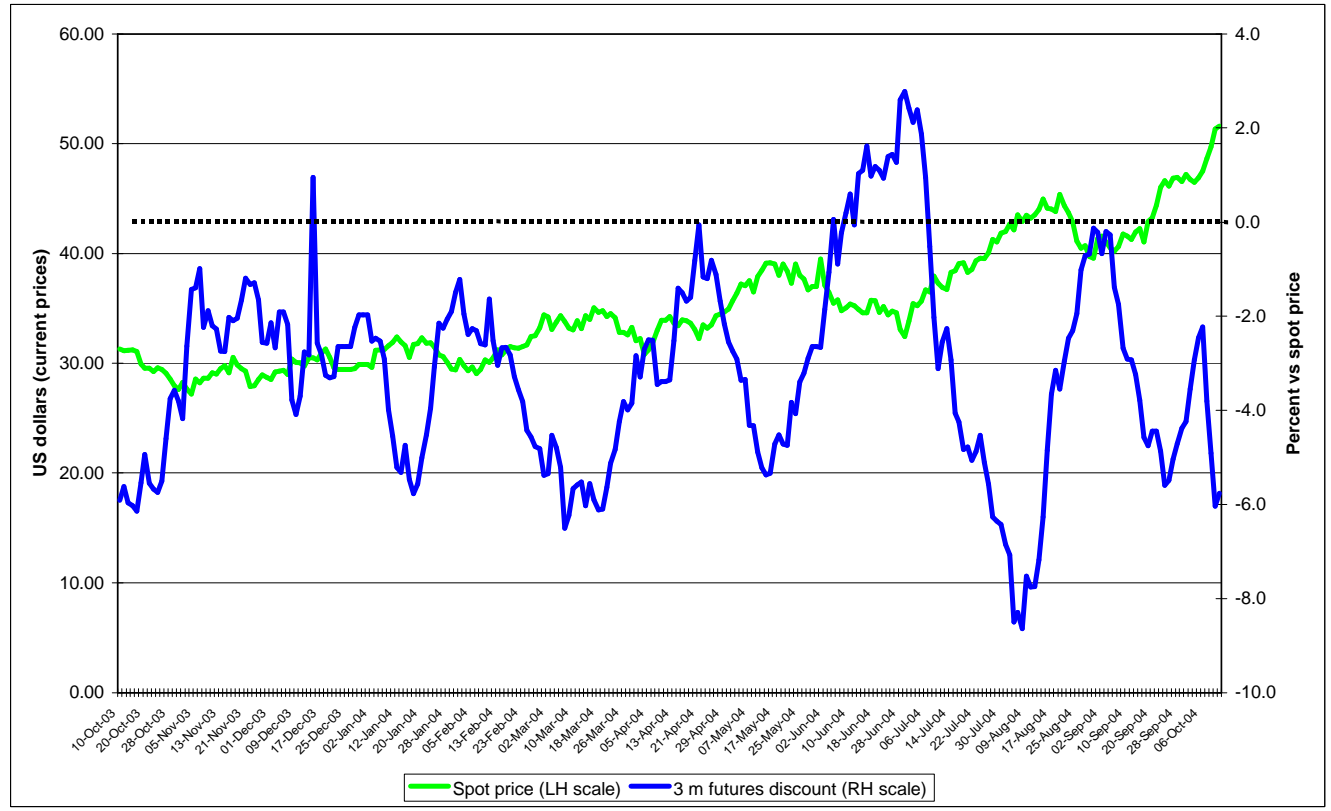

Figure 2. Brent Crude physical (spot|) and 3 month futures price trends

Source: Datastream 


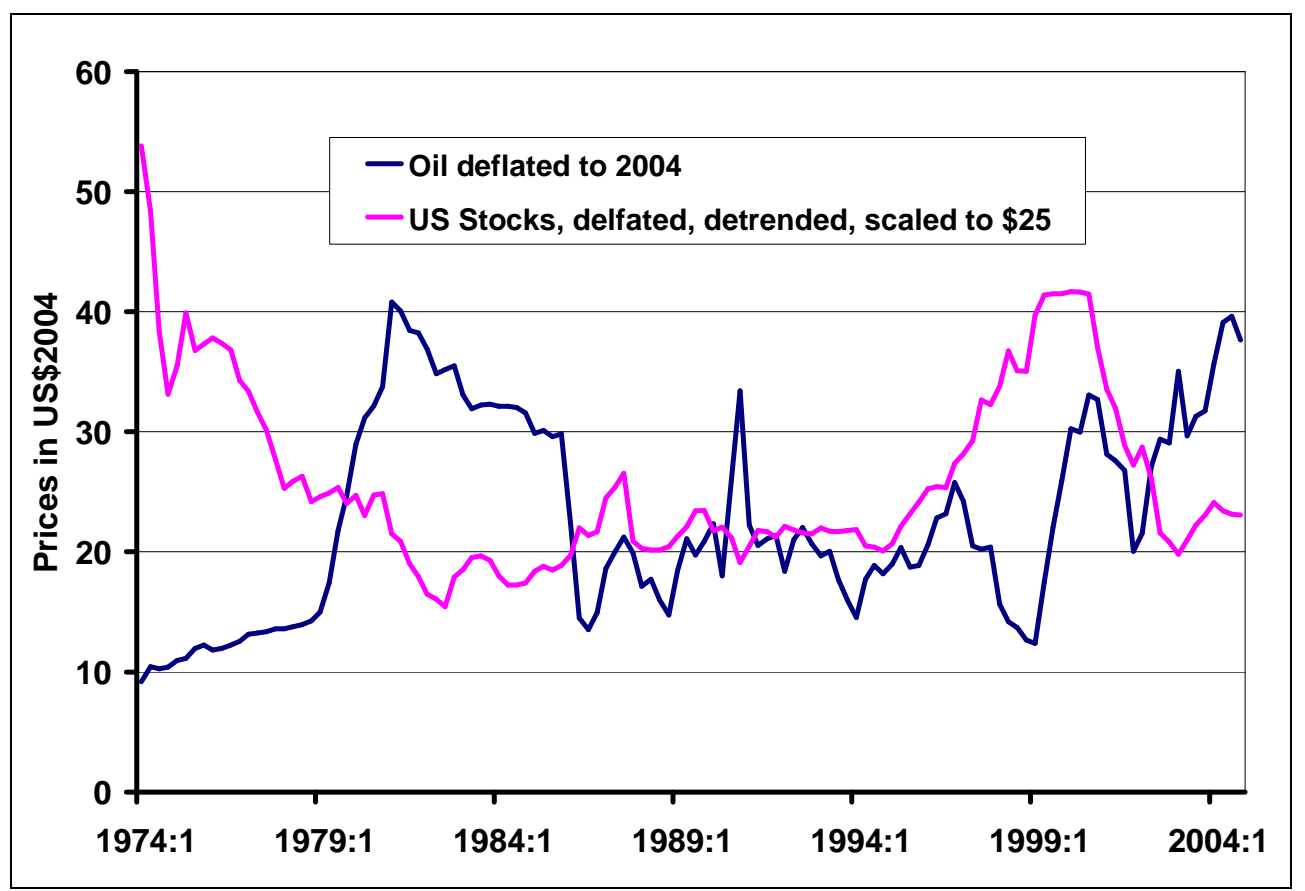

Figure 3. Quarterly oil and stock correlation changes with time

Source: Global Insight 


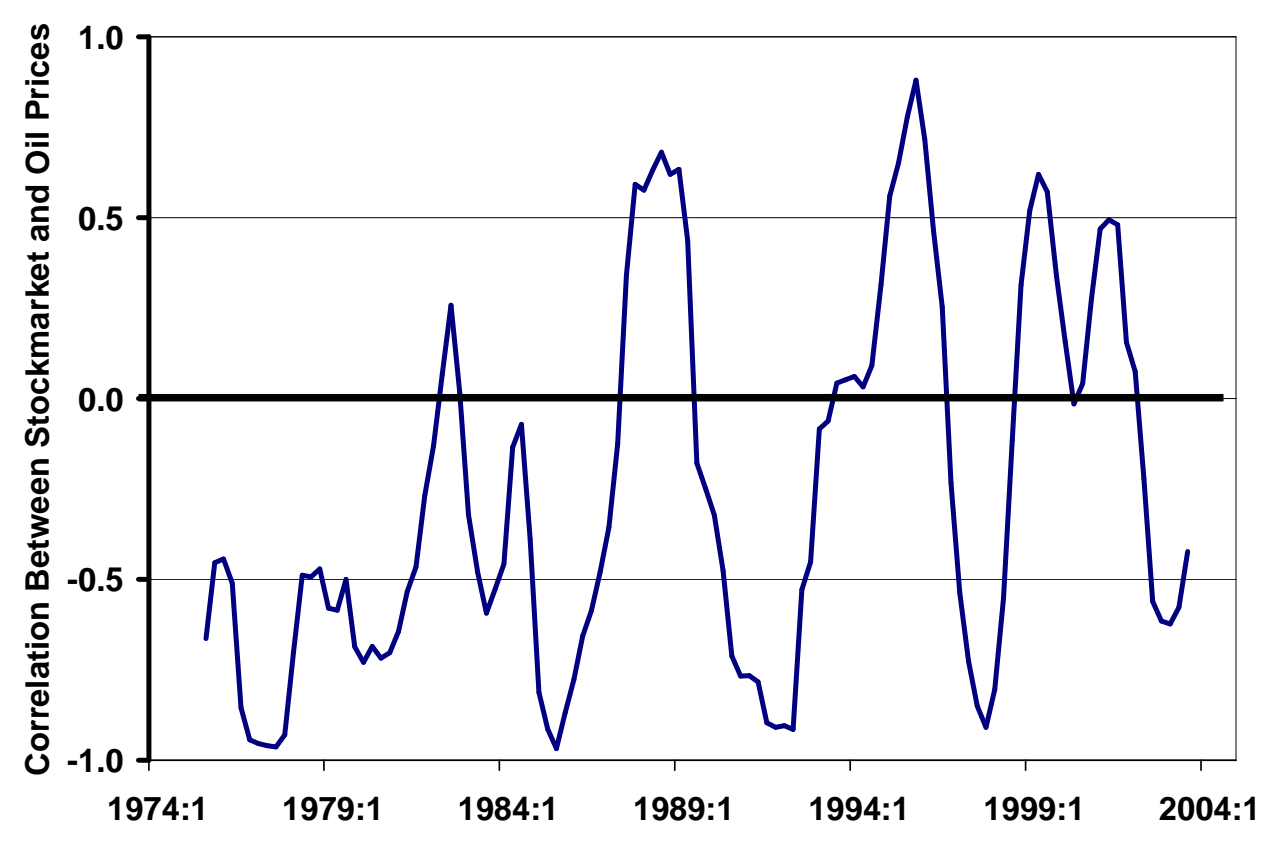

Figure 4. Quarterly oil and stock correlation changes with time 